\title{
V. Die Supermächte und die westeuropäische Sicherheit
}

\author{
Marc Trachtenberg
}

\section{The United States, France, and the Question of German Power, 1945-1960}

Now that the Cold War is over, people look back on that conflict and wonder how seriously it is to be taken. Was there ever a real risk of a Third World War? Didn't Soviet power and American power balance each other so completely in Europe that both sides were more or less locked into the status quo that neither America nor Russia nor any third power had any room for maneuver, and that armed conflict was essentially out of the question? A general nuclear war was such a horrifying prospect, the argument runs, that neither side would want to come anywhere near the point where serious fighting could actually break out; the Cold War peace was therefore stable from the start.

That view, I think, is profoundly mistaken. The sense, particularly strong at certain points, that a third world war was a real possibility, was not just an illusion. But if there was a serious risk of war, what was generating it? Certainly not the ideological conflict alone: the western powers might not have liked Communist rule in eastern Europe, but they were never prepared to go to war to liberate that area; and the Soviets, for their part, were not going to risk war to impose Communist regimes on western Europe. So why then weren't both sides locked into the status quo - more or less forced, that is, by power realities to accept things as they were in Europe?

This is the great puzzle of the Cold War. Why didn't the division of Europe lead, immediately and directly, to a stable international order? Why didn't we have a simple spheres-of-influence system, where each side accepted, in fact if not in words, the other side's predominance on its side of the line of demarcation - a system, that is, in which the two sides, no matter how they felt about the arrangement, respected each other's power and coexisted with each other on that basis? Where, in other words, was the clash coming from? Given the division of Europe, what could possibly generate a real risk of war? To answer that question is to understand what the Cold War was about. 
The key point to note here is that while the western powers were willing, practically from the start, to live with the status quo in Europe, the Soviet attitude was somewhat different. The Soviets had no problem accepting the division of Europe, and as a general rule were prepared to give the western powers a free hand on their side of the line of demarcation. But there was one very important exception to that policy. That exception had to do with Germany. From the Soviet standpoint, German power had to be kept limited; Germany could not be allowed to become a great power again, capable of posing a basic challenge to the status quo in central Europe. This was an area where the Soviets felt that their most basic interests were engaged. They therefore felt that this issue, if necessary, had to be dealt with before it got out of hand. Depending on power realities, this implied that in certain circumstances force might have to be used. The threat of force was a fundamental instrument of policy; for that threat to be effective, the Soviets might have to be prepared, in the final analysis, to follow through on it. The USSR could most easily make the western powers take her concerns about Germany seriously by threatening their position in Berlin, and a Berlin crisis could develop a momentum of its own; a major crisis in that area could conceivably lead to an armed conflict, and thus possibly to a third world war.

The German question therefore lay at the heart of the Cold War. And this meant that the arrangements the western countries worked out among themselves were of fundamental political importance, both in terms of east-west relations and in terms of the stability of international politics in general. It was not as though there were NATO problems and problems between the two blocs, and that those two sets of problems were only marginally related to each other. All these issues were tightly intertwined. The basic question had to do with how much power Germany was to have - whether Germany would reemerge as a truly independent power, able to chart her own course in international affairs, or whether Germany (and that meant essentially West Germany) would be dependent on her allies and thus forced to live with the status quo. If the West developed a political system which kept Germany from becoming too strong and independent, this was something the Soviets could accept, that is, they could live with a system of that sort. But if it seemed that the West had embarked upon a course that would lead eventually to a full resurgence of German power, the Soviets felt they might have to take action - action that might conceivably lead to war.

So if the German question lay at the heart of the Cold War, the settlement of that conflict depended on how the problem of German power was resolved - that is, on whether the western countries were able to build a political system that could effectively control German power. And by late 1954, it seemed that a system of this sort had been constructed. In two great conferences held first in London and then in Paris, the western powers and the Federal Republic of Germany quickly worked out a series of agreements. The Paris accords, as this set of arrangements came to be called, was (as Georges-Henri Soutou has pointed out) the great settlement between the Federal Republic and the three western powers, the equivalent in the post-World War II period of the Versailles settlement after World War I. 
And this was a settlement that limited German power in major ways. Although it is often said that with the ratification of the Paris accords, Germany recovered her sovereignty, this is not quite correct. The Paris accords set up a regime of constrained German sovereignty. The western powers retained the right to station military forces on German soil and to take whatever action was needed to protect those forces. This meant that they retained the right to intervene in extreme cases in internal German affairs, and also the right to use those forces to deal with threats from the east; in both cases the German government did not, in the final analysis, have to give its consent before allied forces could be used ${ }^{1}$. The Federal Republic, moreover, did not have the right, as a sovereign power, to negotiate a reunification agreement on her own; in particular, the western powers could legally block any settlement that provided for German neutralization and for the withdrawal of their troops ${ }^{2}$. West Germany would have a national army, but that army was to be integrated into the NATO structure; and one fundamental goal here was to make it impossible for that army to operate independently ${ }^{3}$.

1 The point that the western powers, under the Paris accords, retained the right to intervene in extreme cases if the democratic system in Germany were threatened is not widely understood, because the existence of this right was not clear from the text of the October 1954 convention governing relations between the Federal Republic and the three western powers. In fact, the provision in the unratified May 1952 contractual agreement that had explicitly authorized the allied authorities to declare a state of emergency and to take appropriate action, should the democratic order be endangered, had been dropped when the basic convention was renegotiated in 1954. But this basic allied right had not disappeared. Another section of the 1952 treaty had given each of the three western military commanders the right to take whatever action was necessary "to remove the danger" if the forces under his command were menaced. The western foreign ministers had decided that this provision in itself - that is, "independently of a state of emergency" - would allow the allies to take action if the democratic regime in Germany were threatened, since the overthrow of the democratic order would automatically endanger the security of the western troops. Since this provision was embarrassing to the pro-western German chancellor Konrad Adenauer, the allies agreed to delete it from the final 1954 agreement provided that it was retained as a "practical arrangement". Adenauer went along with that solution. He gave the allies a written assurance that the deletion of the clause would change nothing because it was an "inherent right of any military commander" to take whatever action proved necessary to protect the forces under his command. The allies thus had a broad and rather loosely-defined right to intervene in extreme cases in internal German affairs. Convention on Relations, May 26, 1952, United States, Department of State, Foreign Relations of the United States, 1952-54, vol. 7, 115 [henceforth cited in the form: FRUS 1952-54, 7:115]. Acheson-Schuman-Morrison meeting, September 13, 1951, FRUS 1951, 3:1273. Kidd memorandum on German sovereignty, September 10, 1954 , and report on termination of the occupation, October 2, 1954, reference to paragraph 7 in the convention on relations, FRUS 1952-54, 5:1169, 1341. For the Adenauer assurance, see Beate Ruhm von Oppen (Ed.), Documents on Germany under Occupation, 1945-54 (London 1955) 628. Note also Dulles's report to Eisenhower on this point, November 12, 1954, quoted in Paul Stares, Allied Rights and Legal Constraints on German Military Power (Washington 1990) 11-12.

2 For the seriousness with which Eisenhower took these rights, see his remarks in an NSC meeting held on February 6, 1958. The summary of discussion is in the Ann Whitman File, NSC series, box 9, Eisenhower Library, Abilene, Kansas.

${ }^{3}$ See Gruenther to Dulles and Conant, September 16, 1954; report on Dulles meetings with 
This whole system was anchored in the most important part of the accords, the provisions governing the Federal Republic's nuclear status. In formal terms, the German government promised not to build nuclear weapons on its own territory, a promise that the allies had the right to enforce; but the settlement was understood in somewhat broader terms. The assumption was that Germany was not to acquire a nuclear force under her own control. And since a non-nuclear Germany could never stand up to a great nuclear power like the Soviet Union on her own, Germany's non-nuclear status implied that the Federal Republic would be dependent on her allies for protection and could therefore not be fully independent in political terms. It followed that she would have to accept a purely defensive policy, the policy her allies had in effect adopted, and could thus pose no threat to the status quo.

This was a system the Soviets could live with because it solved their number one security problem: the control of German power ${ }^{4}$. And the Germans, in the final analysis, could also live with it if they had to - mainly because it provided for their security, but also because it represented their acceptance into the western world on an equal, or nearly equal, basis, with all that implied in political, economic, and even moral terms. As for the other west Europeans, it was close to ideal. For the French in particular, it solved at one blow the two great problems they had to contend with in the postwar period: the Russian problem and the German problem. The NATO alliance, a system built on American power, would keep the Soviet threat at bay. At the same time any possible German threat would be contained in a structure dominated by American power.

The French, or at least the more perceptive French policymakers, had, in fact, seen the advantages of such a system relatively early on, a good deal earlier than is generally admitted. In 1946 and 1947, America and Britain had adopted what was called the "western strategy" for Germany: the policy of creating a west German state, oriented toward the western world economically, culturally, politically, and, in the final analysis, militarily, a state under the military protection of the western powers, and aligned with those powers in the developing conflict with the USSR. This was a strategy that implied the eventual liquidation of the occupation regime. The controls would gradually be dismantled; one could count on the threat from the east to hold the Germans on the western side. Key French officials - the foreign minister, Georges Bidault, above all - saw eye-to-eye with the Anglo-Sa-

Adenauer and Eden, September 16-17, 1954; Gruenther to Dulles, September 19, 1954; Gruenther-Dulles meeting, September 27, 1954; and Dulles to Eisenhower, September 28, 1954; in: FRUS 1952-54, 5:1199-1201, 1219, 1228, 1282, 1293.

4 Our understanding of Soviet policy in this area remains incomplete, but for an interpretation along these lines by a scholar who had worked in the Soviet archives, see Vladislav Zubok, Soviet Intelligence and the Cold War: The Small' Committee of Information, 195253, in: Cold War International History Project Working Paper [CWIHP] working paper series, no. 4 (1992) 10; Vladislav Zubok, Khrushchev and the Berlin Crisis (1958-1962), in: CWIHP working paper series, no. 6 (1993) 3; and Yuri Smirnov, Vladislav Zubok, Nuclear Weapons after Stalin's Death: Moscow Enters the H-Bomb Age, in: CWIHP Bulletin (Fall 1984) 17. 
xons in this area practically from the start, although they could not say so openly until 1948 because of political circumstances within France 5 . But for them, a system based on the division of Germany, with western Germany integrated into the western system more or less voluntarily - indeed, a system based on sufficient tension between east and west to keep the Americans in Europe and to keep the Germans dependent on the western side for protection - was the best arrangement they could possibly hope for ${ }^{6}$. To be sure, Germany's status would be transformed - but not quite to the point where Germany would become a full partner. And to be sure, Germany would eventually have to be rearmed, but here too there were limits as to how far this process could go. But those changes were acceptable, since the construction of the western system (including the integration of the Federal Republic into the western bloc as an almost-equal partner) would solve both the German problem and the Russian problem. And that solution would be stable: unlike the 1919 settlement, this was an arrangement everybody could live with.

So the French attitude - or at least the attitude of the French foreign ministers from the period, Bidault and then Schuman, along with their main advisors - was more in line with the Anglo-American position than people think. In 1949, for example, the French actually took the lead in pressing for a relatively liberal occupation statute for Germany 7 . And in 1950, the French government was not nearly as opposed to an eventual rearmament of Germany as is often claimed. Schuman and other key officials personally agreed with the Americans on a whole range of basic issues: the importance of drawing Germany into the West and transforming her into a partner; the need for an effective ground defense in Europe and the impossibility of achieving this without a German contribution; and the desirability

5 Thus Bidault and Jean Chauvel, the top permanent official at the Quai d'Orsay, repeatedly told the Americans in mid- and late 1946 that they sided with the United States in the developing dispute with the Soviets over Germany, and that it was only for "internal political reasons" that France could not overtly stand with America. See Caffery to Byrnes, June 11, June 22, and August 30, 1946, in: FRUS 1946, 5:566-567, 567n, 596.

6 This sort of thinking was reflected, for example, in draft instructions to the foreign minister from about August of 1949, establishing the line that the status quo of a divided Germany was the best solution from the French point of view: "Nous pouvions craindre à la fois un accord plus vaste, ou une rupture complète: la solution intervenue était la meilleure." Europe 1949-55/Allemagne/vol. 254/f. 41 (p. 10 in original document), French Foreign Ministry Archives [FFMA], Paris.

7 This was in part due to the fact that the policy of integrating Germany into the western system as a real partner had to a certain extent been sabotaged by the French military administration in Germany. Schuman and his associates had therefore concluded that it was important to transform the system - to replace the military governors with a civilian High Commission, and to relax the occupation controls. On the French role in bringing about a major liberalization of the occupation regime in early 1949, see Kennan notes of meeting with François-Poncet, March 21, 1949, and Acheson-Schuman meeting, April 1, 1949, in: FRUS 1949, $3: 114,159$. On the undermining of the Schuman policy by the French occupation authorities in Germany, see for example Massigli to Chauvel, February 14, 1949, Massigli Papers, vol. 68, FFMA. Note also the U.S. impression that low-level French officials in Germany were pursuing a policy of their own; meeting of U.S. ambassadors, March 22-24, 1950, in: FRUS 1950, $3: 818$. 
of integrated structures that could provide a stable long-term basis for limiting German freedom of action. In September 1950, when the Americans demanded that Germany be rearmed, Schuman made it clear that he personally understood the need for German troops. He fully agreed that it was illogical to think that Germany should be defended without a German contribution. He was ready to accept the principle of a German defense contribution providing this could be done secretly, but the Americans were insisting on public acceptance now. The problem, he said, was that in France only a minority understood "the importance of Germany in western defense". It was politically impossible for him to do what the Americans wanted immediately. The French public was simply not ready to go along with German rearmament at this point. It would be better first to let the NATO regime take shape, for a U.S. general to come over as NATO commander, for a U.S. combat force to take up positions in Germany. After those things were done, it would be much easier to get the French parliament to accept some form of German rearmament ${ }^{8}$.

And in late 1954, it was the French government that took the lead in working out the arrangements that were later embodied in the Paris accords. The French prime minister, Pierre Mendès France, allowed the plan for a European Defense Community to be voted down by the French parliament. He then quickly accepted the idea of a German national army and the direct admission of Germany into NATO. He had, in fact, begun to press for a solution of this sort at a time when the Americans still had their hearts set on the EDC, and when the British, out of loyalty to America, were still urging the French government to push the EDC treaty through parliament. But Mendès saw that this course of action was hopeless, that the NATO solution was better in any case, and that the sort of arrangement that was finally worked out - the limits on German power embodied in the Paris accords - was all that was needed?

${ }^{8}$ See Bevin to Foreign Office, September 13, 1950; Harvey to Bevin, October 7, 1950; and Schuman-Bevin meeting, December 2, 1950; in Documents on British Policy Overseas, series II, vol. 3, 35-36, 136, 312-317. See also Schuman-Acheson meeting, September 12, 1950; meeting of western foreign ministers and high commissioners, September 14, 1950; Acheson to Truman, September 14, and September 16, 1950; and Schuman-Bevin-Acheson meeting, September 12, 1950; in: FRUS 1950, 3:287-288, 296-303, 311-312, 1200. By the Americans' own account, Schuman's domestic political problems were quite real. American officials had long recognized that the French foreign minister "was following a very difficult and narrow road on Germany", that if it were not for him, the French would not have moved as far as they had, that he was "balanced on a needle" and, because of the internal political situation in France, it was important that he "not be pushed too far". U.S. ambassadors' meeting, March 22-24, 1950, ibid. 819.

9 See especially Mendès-Eden-Churchill meeting, August 23, 1954, and Mendès to main French ambassadors, September 18,1954, in: Pierre Mendès France, Oeuvres complètes, vol. 3 (Paris 1986) 246-247, 317-321. Note also Massigli to Mendès, September 9, 1954, and Parodi to Massigli, September 9, 1954, with Mendès draft proposal, France, Ministère des Affaires Etrangères, Documents diplomatiques français, 1954, 308-310, 312-315. For the real British view of the EDC, see especially Dulles to Eisenhower, September 18, 1954, in: FRUS 1952-54, 5:1227. Churchill, Dulles reported, had said he was glad the "EDC tomfoolery" 
So what went wrong? The problem at this point is to explain why the system embodied in the Paris accords did not lay the basis for a stable peace, for it is clear that the arrangements worked out in 1954 did not lead to the kind of system both sides felt they could live with. Just four years later, a new period of crisis began, and the world would have to wait until 1963 before the threat of war receded, this time permanently.

Why then did the Paris system fail? The answer has to do, above all, with American policy. The NATO system would work only if, and only if, the Americans remained present in Europe, for how could the Germans be expected to remain non-nuclear if the United States was not there to protect them? How could they be expected to stand up to a great nuclear power like the USSR essentially on their own? There had to be some counterweight to Soviet power in Europe. If the Americans could not provide it, the west Europeans would have to do it themselves. But a real political unification of western Europe was not imminent. If the war-making power could not be vested in some supra-national European authority - if a true pooling of sovereignty in that area was simply not in the cards, if a real United States of Europe remained a distant dream - then any European force would have to be organized on what was, in the final analysis, a national basis. Yet a German "finger on the nuclear trigger" was not something that the Soviets would readily accept; the prospect of a nuclear force under German control could easily lead, as indeed it did in late 1958, to a new period of crisis.

The issue of the American military presence in Europe was therefore of fundamental importance. The stability of the system - the viability of the arrangement that had been worked out in 1954, a system that limited German power in fundamental ways - turned on the willingness of the Americans to commit themselves to the defense of western Europe on a more or less permanent basis.

But it took many years before the Americans finally accepted the idea that they were committed in Europe for good. In the 1940s, the American attitude in this area remained ambivalent. In 1948, for example, some American policymakers wanted western Europe to become an independent center of power, a "third force" strong enough "to say ,no" both to the Soviet Union and to the United States"10. The feeling was that the Europeans had the resources to defend themselves, if only they would unite politically. Unification would also solve the German problem, and was probably the only solution if the United States was not to keep forces in Europe forever. So the American attitude toward European inte-

was over, that "he had only supported it because" Eisenhower had wanted it, but that he "had never had faith in it". Indeed, all along Churchill had sought to keep the door open for the simpler solution of admitting Germany directly to NATO. See also his remarks at the Bermuda conference, December 6, 1953, ibid. 1803.

10 Hickerson-Inverchapel meeting, January 21, 1948; Hickerson in U.S.-U.K.-Canada talks, March 23, 1948; Douglas to Lovett, April 17, 1948; in: FRUS 1948, 3:11, 64, 91. On "third force" thinking at this time, see also the quotation from an unpublished State Department history of the Marshall Plan, in: Max Beloff, The United States and the Unity of Europe (Washington 1963) 28. 
gration was unambiguous. "We favor it", Secretary of State Acheson told Schuman in 1950, "I favor it." This was the way, he said, to build a Europe strong enough to defend itself "against the attacks of Communist nihilism and Soviet imperialism," and it was "the soundest basis on which this generation could reinsure the next against another dangerous German aberration"11.

On the other hand, the Americans gave certain assurances that they were not going to withdraw so long as there was a need for a counterweight to Soviet power in Europe. In early 1948, in fact, as part of the process leading to the London Recommendations - the agreements that provided the framework for the establishment of a west German state - the U.S. government made certain formal commitments along those lines. "As long as European Communism threatens US vital interests and national security", Secretary of State Marshall wrote on February 28, "we could ill afford to abandon our military position in Germany." "The logical conclusion", he added, "is that three-power occupation may be of unforeseeable and indefinite duration, thus offering protracted security guarantees and establishing a firm community of interests." The maintenance of the occupation, he pointed out, meant in particular that the French would be secure against Germany ${ }^{12}$. And on March 17, President Truman declared officially that American forces would stay in Germany until the Communist threat had come to an end; this promise was incorporated into the June 1 three-power agreement on Germany, giving it a certain contractual force ${ }^{13}$.

But these commitments, as it turned out, were not taken as binding. Even in mid-1951, Acheson was still thinking in terms ultimately of a purely European solution. America, he assumed, would eventually withdraw from Europe, but when she did, some sort of integrated military system had to be left behind. A situation where nothing would remain on the continent "except national forces solely under national control" - and that meant mainly a German army under German control - had to be avoided. A "workable European army" was thus the aim; "practical steps" toward that goal should be taken even in the short run; a European system would eventually evolve out of the present U.S.-dominated NATO structure ${ }^{14}$.

But by the end of July, this line had been abandoned. Acheson had been convinced by his subordinates that a purely European system would never be viable. He now attacked what he called the growing tendency to "treat European integration and a European Army as final solutions for all problems including that of

11 Acheson to Schuman, November 29, 1950, in: FRUS 1950, 3:496-498.

12 Marshall to Douglas, February 28, 1948, in: FRUS 1948, 2:101.

13 For Truman's pledge, see his address to Congress, March 17, 1948, in: Department of State Bulletin (March 28, 1948) 418. For the formal security commitment and the related U.S. agreement to coordinate policy with her main allies, see Douglas to State Department, May 19 and May 30, 1948, Report of London Conference, June 1, 1948, agreed paper on security (Annex L of the report), and London Communiqué, June 7, 1948, in: FRUS 1948, 2:256, 292, $301 n ., 312,316$.

14 Acheson to Bruce, June 28, 1951, and Acheson memorandum, July 6, 1951, in: FRUS 1951, $3: 802,804,816$. 
security against Germany", and he criticized what he no now saw as an unfortunate tendency in American circles to disregard the long-range importance of developing the Atlantic community as a whole. Just two weeks earlier, he had taken it for granted that the American presence would be temporary, but he now explicitly rejected the notion that U.S. participation in NATO would "terminate at some indefinite time in the future". America's "long-term interests" would be "best served" not just by the development of the European Army plan, but by a "policy of permanent association" with the NATO allies for the defense of the Atlantic area as a whole. And the reason had more to do with Germany than with Russia: the west Europeans, he now thought, were probably not strong enough "by themselves to outweigh German influence" in the future European Army ${ }^{15}$.

But this was a false dawn. Less than two years later, a new government came to power in Washington, and the old notion of western Europe as a "third force", independent of the United States, reemerged as a central tenet of American policy. The new president, Dwight Eisenhower, knew what he wanted. The United States, he felt, was not cut out to be an imperial power: "We cannot", he said, "be a modern Rome guarding the far frontiers with our legions if for no other reason than that these are not, politically, our frontiers." 16 The Europeans, in the final analysis, had to defend themselves. They certainly had the resources to do so. Faced with the great threat from the east, they should put their petty national differences aside and unite both politically and militarily. If they came together, they would be able to balance Soviet power on their own. Western Europe, Eisenhower concluded, should become "a third great power bloc". When that happened, he explained in 1955, the United States would no longer have to bear the enormous burden of providing for the defense of Europe. America could then "sit back and relax somewhat" 17 .

This sort of thinking lay at the heart of the Eisenhower administration's European policy. It was because the new U.S. leaders saw the situation in those terms that they pushed so hard for the ratification of the EDC. They backed that plan not because it was the only way, given French concerns about a German national army, to get a German military contribution. Even when the French made it clear that they preferred the NATO solution (which military officers on both sides of the Atlantic almost universally viewed as far superior in military terms), the U.S. government still pressed as hard as it could for the establishment of the EDC. For Eisenhower, a solution based on national armies "was a second choice so far be-

15 Acheson to Bruce, July 16, 1951; cf. Acheson to Bruce, June 28, 1951, in: FRUS 1951, 3:802, 835 .

${ }^{16}$ Eisenhower to Bermingham, February 28, 1951, in: Louis Galambos et al. (Eds.), Papers of Dwight David Eisenhower, vol. 12 (Baltimore 1989) 76-77. Emphasis in original.

17 NSC meeting, November 21, 1955, in: FRUS 1955-57, 19:150-151. Note also the president's reference to the importance of western Europe uniting and becoming "a third great power complex in the world", in: Eisenhower to Gruenther, December 2, 1955, Eisenhower Papers, vol. 16, 1919-20. Eisenhower had long been thinking along these lines. See, for example, his remarks at a White House meeting, January 31,1951, and to the North Atlantic Council, November 27, 1951, in: FRUS 1951, 3:450-451, 734. 
hind EDC that there could be no comparison." The fundamental objective was political and not military in nature. The real point of the EDC, he and Secretary of State Dulles both felt, was to weld France and Germany together as the core of a strong European federation that could stand up to Russia on its own ${ }^{18}$. They were therefore livid when Mendès France allowed the EDC project to collapse, and reacted coolly to the Anglo-French effort to work out an alternative based on establishment of a German national army within NATO $^{19}$.

The Americans, in the final analysis, felt they had little choice but to accept the arrangements worked out in late 1954. But their acceptance of the system established by the Paris accords, a system based on a continuing, large-scale American military presence in Europe, was never whole-hearted. If Eisenhower said it once, he must have said it a thousand times: the American troop presence was never meant to be permanent; it was originally supposed to be a stopgap measure; the idea had been to protect the Europeans during the period when they were building the forces they needed to defend themselves ${ }^{20}$. Paris accords or no Paris accords, this remained his basic concept.

The great test of Eisenhower's seriousness in this area was his policy on the nuclear sharing issue - that is, on the question of European control of nuclear forces. If the Europeans were to be independent of America, if they were to stand up to Soviet power on their own, they would obviously need nuclear forces under their own control. And the key point to note about the Eisenhower policy was that he very much favored the Europeans acquiring a nuclear capability of their own.

Eisenhower, of course, did not want a whole series of totally independent European nuclear programs. The more unity there was within the alliance, the more unity there was especially within western Europe, the better from his point of view. America had at great expense built up an enormous nuclear infrastructure. The best thing would be for the United States to treat the NATO countries as real

18 For Eisenhower's comment: meeting of American, British, and French leaders, December 5, 1953, in: FRUS 1952-54, 5:1783. For the U.S. view that the EDC was important for political far more than for military reasons, see the Annotated Order of Business at Bermuda, Dulles State Papers [hereafter DSP], reel 12, frame 16320, Mudd Library [ML], Princeton University, and also Dulles-Mendès meeting, September 27, 1954, p. 4, State Department Conference Files, CF 370, RG 59, U.S. National Archives [USNA].

19 Dulles meeting with State Department officials, August 25, 1954, DSP/64/62973/ML; Dulles-Bonnet meeting, September 14, 1954, DSP/64/63054/ML; Dulles-Adenauer meeting, September 16,1954, p. 6, DSP/64/63071/ML. Note also the grudging tone of Dulles's remarks at the conference where the NATO solution was worked out, and also in the NSC meeting of October 6, 1954, in: FRUS 1952-54, 5:1357-61, 1379-82. The point that Eisenhower and Dulles disliked the 1954 system and accepted the Paris accords grudgingly is not commonly understood. Indeed, one major work on Eisenhower gives the president the credit for engineering this settlement. See Stephen Ambrose, Eisenhower, vol. 2 (New York 1984) 215-216.

20 Many documents record Eisenhower expressing views of this sort. For a representative sample, see FRUS 1952-54, 2:444-445, 456; FRUS 1952-54, 5:386, 370, 450-451, 483; FRUS 1955-57, 5:274; FRUS 1958-60, 7(1):444, 479, 508, 516, 519. See also Marc Trachtenberg, History and Strategy (Princeton 1991) 185 n. 56. 
allies and supply them with the weapons and the technology they needed. The U.S. government should in particular support whatever collaborative efforts the Europeans embarked upon in that area.

All this may be a little hard to accept, especially since the published documents have been edited (or "sanitized", to use the official term) to give a misleading impression of what American policy actually was ${ }^{21}$. But the archival evidence makes it abundantly clear that Eisenhower, and Secretary of State Dulles as well, supported the idea of European nuclear independence. Thus, in late 1957, France and Germany, later joined by Italy, embarked on the path of nuclear cooperation. A number of agreements, the so-called FIG [France-Italy-Germany] agreements, were signed at this time 22 . The goal was to create a "European strategic entity": the Europeans would develop some sort of nuclear capability of their own ${ }^{23}$. The

21 Thus all references to a NATO nuclear force whose use would not be subject to a U.S. veto were deleted from the extracts from the Bowie report of August 1960 that appeared in FRUS 1958-60, 7(1):622-627 - despite the fact that an unedited version of the report had been declassified and made available through the Nuclear History Program years earlier. One should also compare the full version of the Dulles-von Brentano meeting of November 21, 1957, found in the archives $(740.5 / 11-2157$, RG 59, USNA), with the sanitized version published in FRUS 1952-54, 4:193-206. The passages deleted from pp. 197 and 202 in the published version totally change the impression one gets from the document. The thrust of Dulles's remarks was that the system would have to be changed so that the allies could be sure that the weapons would be available to them in an emergency, that there could not be "first and second class powers in NATO", and that indeed the regime established by the Paris accords might have to be changed. For examples of how even the best European scholars are misled, note the way the sanitized document is used in Maurice Vaïse, Aux origines du mémorandum de septembre 1958, in: Relations internationales, no. 58 (summer 1989) 261-262; and Peter Fischer, Die Reaktion der Bundesregierung auf die Nuklearisierung der westlichen Verteidigung (1952-1958), in: Militärgeschichtliche Mitteilungen 52 (1993) 127-128.

22 On the FIG agreements, see Colette Barbier, Les négociations franco-germano-italiennes en vue de l'établissement d'une coopération militaire nucléaire au cours des années 19561958, Eckart Conze, La coopération franco-germano-italienne dans le domaine nucléaire dans les années 1957-1958: Un point de vue allemand, and Leopoldo Nuti, Le rôle de l'Italie dans les négociations trilatérales, 1957-1958, in: Revue d'histoire diplomatique (1990), nos. 1-2; Peter Fischer, Das Projekt einer trilateralen Nuklearkooperation, in: Historisches Jahrbuch 112 (1992) 143-156, and also Fischer, Die Reaktion der Bundesregierung 125-129; Hans-Peter Schwarz, Adenauer, vol. 2 (Stuttgart 1991) 332, 394-401; and above all GeorgesHenri Soutou, Les accords de 1957 et 1958: vers une communauté stratégique et nucléaire entre la France, l'Allemagne et l'Italie?, in: Maurice Vaïsse (Ed.), La France et l'atome: Etudes d'histoire nucléaire (Brussels 1994), and Soutou, L'alliance incertaine: Les rapports politicostratégiques franco-allemands, 1954-1996 (Paris 1996) ch. 3-4. Another scholar has pointed out that high French military officers (Generals Stehlin and Valluy) had raised the issue of nuclear cooperation with the top German military officer, General Heusinger - in America, incidentally - as early as July 1956. Christian Greiner, Zwischen Integration und Nation: Die militärische Eingliederung der Bundesrepublik Deutschland in die NATO, 1954 bis 1957, in: L. Herbst (Ed.), Westdeutschland 1945-1955: Unterwerfung, Kontrolle, Integration (Munich 1986) 275; also cited in Greiner's article in: Hans Ehlert et al., Anfänge westdeutscher Sicherheitspolitik, vol. 3 (Munich 1993) 737, 739.

23 Georges-Henri Soutou, Les problèmes de sécurité dans les rapports franco-allemands, in: Relations internationales 58 (summer 1989) 229. 
German chancellor, Konrad Adenauer, told Dulles about the FIG project at the NATO Heads of Government meeting in Paris in December 1957. Dulles's attitude was not the least bit hostile. He brought up the possibility of broadening the arrangement and creating "something like a nuclear weapons authority" that would include the three continental countries plus America and Britain ${ }^{24}$. A few months later, the U.S. Secretary of Defense, Neil McElroy, told the NATO defense ministers that his government had "no objection" to such arrangements as the "French-Italian-German collaboration, provided that the work is carried out under the aegis of NATO". "In that event", he added, "the U.S. would be able to furnish technical and certain financial assistance." 25

The preference was for collaborative arrangements, but the Americans at this point were not insisting on a structure that was so tight as to make national use impossible. Eisenhower's idea was that the allies - first within NATO and then ultimately within a purely European framework - would cooperate with each other voluntarily. For Eisenhower, it was normal and natural that the European countries would want to develop nuclear forces of their own - that is, forces ultimately under the control of their national authorities ${ }^{26}$. Germany was not considered an exception to this general rule: the Federal Republic, in Eisenhower's view, was one of the countries (referred to in the documents as "selected NATO allies") that could be helped to acquire a nuclear capability ${ }^{27}$.

All this must be taken quite seriously. Eisenhower was not just daydreaming about an eventual American withdrawal from Europe, about western Europe becoming a "third great power bloc", and about the major European allies getting nuclear forces under their own control. The seriousness of the Eisenhower policy was reflected in what was actually done. By the end of the Eisenhower period, the NATO allies, including Germany, had acquired effective control over substantial numbers of American nuclear weapons. And this, it seems evident, was a direct result of the Eisenhower policy ${ }^{28}$.

${ }^{24}$ Dulles-Adenauer meeting, December 14, 1957, Declassified Documents Reference System (microfiche), 1987/750. The idea of some kind of NATO nuclear authority may have been planted in the Americans' minds by the French. France's NATO ambassador, Crouy-Chanel, had met with Norstad on October 26 and had proposed a NATO "mechanism involving a common effort in the field of modern weapons, including evaluation, production and common use". Thurston to Timmons, October 29, 1957, 740.5611/10-2957, RG 59, USNA.

25 Elbrick to Dulles, April 24, 1958, in: FRUS 1958-60, 7(1):318. Note also Quarles's remarks in meeting with Pineau and McElroy, November 20, 1957, in: FRUS 1955-57, 27:203. 26 See especially Eisenhower's remarks in an NSC meeting, October 29, 1959, in: FRUS $1958-60,7(2): 290$, and in a meeting with General Norstad, August 3, 1960, in: FRUS 1958$60,7(1): 610$.

27 NSC meetings, July 16 and 30, 1959, in: FRUS 1958-60, 3:260-261, 288-289, and also the Eisenhower-Norstad meeting cited in $\mathbf{n} .26$.

${ }^{28} \mathrm{By}$ the end of the Eisenhower period, about 500 American nuclear weapons were deployed to non-US NATO forces in Europe. See White House briefing for Joint Congressional Committee on Atomic Energy [JCAE], May 1, 1962, 740.5611, RG 59, USNA. The fact that the Europeans had effective control of those weapons has been widely known for many years. See, for example, Peter Feaver, Guarding the Guardians: Civilian Control of 
The whole thrust of the Eisenhower policy, in other words, was to undermine the system established by the Paris accords - a system that rested on the twin pillars of a non-nuclear Germany and a more or less permanent American military presence in Europe.

What role did the French play in all this? In the past, the French had basically championed the idea of a system based on constrained German sovereignty and a permanent American presence in Europe. They had thrown their weight into the balance on behalf of the NATO system, the sort of system the Paris accords were supposed to establish. At key points that policy had played an important role. But by the late 1950s the French were no longer strong supporters of a system of that sort. Even under the Fourth Republic, the French attitude on the question of a German nuclear force had become ambivalent, to say the least. This, in fact, was the meaning of the FIG affair.

By 1963, under de Gaulle, the French had turned away from the basic idea behind the NATO system: that stability depended on keeping German power limited, and that with Germany weak only the American presence could provide an effective counterweight to Soviet power in Europe. It was not that de Gaulle wanted a strong Germany, although he did toy with the idea of a German nuclear force, conceivably one built in collaboration with France ${ }^{29}$. The real point was that he was never quite sure how the German problem was to be dealt with. Even if he was not comfortable with the idea of a full resurgence of German power, of a Germany with a major nuclear force under her own control, he had not faced up to the question what it would take, in terms of the way the European political system had to be structured, and in particular in terms of the role the Americans would have to play in Europe, to head off such a prospect ${ }^{30}$.

In short, by the end of the Eisenhower period a stable system had still not come into being. The system outlined in the Paris accords had not been given a chance. That system had been based on the premise that Germany would be kept non-nuclear, and thus dependent on her allies and locked into the status quo. The security of western Europe would ultimately be based on American power. But the Americans, under Eisenhower at least, had no interest in supporting a system of that

Nuclear Weapons in the United States (Ithaca 1992) 178-183. The most important archival source on this general subject is the Holifield Report on U.S. nuclear weapons in NATO. Representative Holifield had chaired an ad hoc subcommittee of the JCAE which had been set up to look into the question. The summary portion of the report is enclosed in Holifield to Kennedy, February 15, 1961, and is available at the National Security Archive in Washington.

${ }^{29}$ See, for example, Georges-Henri Soutou, De Gaulle, Adenauer und die gemeinsame Front gegen die amerikanische Nuklearstrategie, in: Ernst Hansen et al. (Eds.), Politischer Wandel, organisierte Gewalt und nationale Sicherheit: Beiträge zur neueren Geschichte Deutschlands und Frankreichs (Munich 1995) 498-499.

30 According to the top permanent official at the Quai d'Orsay, de Gaulle was aware of the problem. He was "more uncertain" about how to deal with the German question than with any other problem on the European scene. Bohlen to Kennedy, February 23, 1963, POL 15-1 FR, State Department Central Files, RG 59, USNA. 
sort, and even major European countries like France were no longer willing to press for this kind of structure.

And deprived of political support, such a system was bound to fail. The result was that things began quickly to move in a direction that the Soviets found hard to tolerate. The specter of a strong Germany, a nuclear-armed Germany, touched on their most sensitive political nerve. They therefore felt they had to force the West to take their concerns seriously. Berlin was the obvious lever, and the Berlin crisis of 1958-62 was a direct result of the failure of the Paris system. The world thus moved into a new period of crisis because the western countries had been unable to construct the sort of political system they themselves had formally agreed to in 1954. 